\title{
Model for the Formulation of Corporate Criminal Liability System in Omnibus Law (Law Number 11 of 2020 Concerning Job Creation)
}

\author{
Rahmi Dwi Sutanti ${ }^{1}$, Claverina Moraosky Pangaribuan ${ }^{2}$ \\ \{rahmidwisutanti@live.undip.ac.id $\left.{ }^{1}\right\}$ \\ Universitas Diponegoro, Indonesia ${ }^{1,2}$
}

\begin{abstract}
The development of criminal legislation outside the Criminal Code has led to corporations as subjects of criminal law, including in the Omnibus Law, Law Number 11 of 2020 concerning Job Creation. It is of course also a deviation from the Criminal Code. This is what encourages the importance of conducting this study, using the normative methods, to analyze the model for formulating a corporate criminal liability in this Law. The issue that is the focus of discussion in this paper is how the formulation of corporate criminal liability in Law Number 11 of 2020 concerning Job Creation and, what is the ideal corporate criminal liability formulation model in an Omnibus Law. The results showed that the structure of the Job Creation Law is different from other ordinary laws, and each cluster mentions corporate criminal liability in a diverse and unsynchronized manner. So, there are no uniformity of corporate criminal liability formulation, and it can lead to juridical problems in its application. From the second problem it can be concluded that the ideal formulation model for corporate criminal liability in an Omnibus Law is to accommodate it in the chapter on general provisions. By entering into general provisions, the regulation will be uniform and applicable to the entire content of the law.
\end{abstract}

Keywords: Corporate Liability, Criminal Liability, Omnibus Law, Indonesia

\section{Introduction}

The formulation of criminal law subjects or targets of criminal law norms in the Criminal Code is based on the University/Societas Delinquere non-Potest principle, which means that legal entities or corporations cannot commit criminal acts. It can be concluded from the formulation of Article 59 of the Criminal Code, which reads: "In cases where the offense is determined to be criminalized against the management of the board members of the commissioners, the management, board members or commissioners who did not interfere committed the violation, not sentenced" [1][2]. This provision shows that the organs of a corporation can be held accountable for committing a criminal act, but it is limited to personal liability, not corporate liability. The legal subjects adopted in the Criminal Code are only humans as individuals (natuurlijke personen). Apart from the existence of the provisions in Article 59, it can also be concluded that the formulation of offenses in the law usually starts with the word "whoever" refers to the subject and refers to "person"; the types of criminal sanctions in Article 10 of the Criminal Code are types of crimes that can only be imposed on humans; and, in the examination of the case and the nature of the criminal law where the 
defendant has seen or not, gives an indication that those who can be accounted for are humans [3][4].

The application of the university principle in the Criminal Code, which underlies the only human subject of criminal law, is slowly starting to be abandoned with the development of legal subjects in criminal law outside the Criminal Code, which allows corporations or legal entities to be held accountable in criminal law. The regulation of corporations as a subject of criminal law in-laws outside the Criminal Code has become common. In purely criminal laws and in various administrative laws that contain criminal sanctions or better known as Administrative Penal Law. The development of corporate law is increasingly showing good effect with the start of investigating criminal acts committed by corporations. The prospect of regulating corporate criminal liability that commits criminal acts deserves serious scrutiny, considering that the regulations exist only in special provisions and not in the general provisions of Book I of the Criminal Code. It indicates no general principles that can be used as a reference in criminalizing corporations, but all the rules come from the special law itself. Such conditions can cause various juridical problems due to the inconsistencies and inconsistencies between specific criminal laws containing criminal provisions for corporate criminals [5]. There have been at least 2 decisions in kracht related to corporations, namely the corruption case committed by PT Giri Jaladhi Wana and the corruption case committed by PT Nusa Konstruksi Enjiniring. The PT Giri Jaladhi Wana (PT GJW) case was examined and decided through the Banjarmasin District Court decision Number 812/Pid.Sus/2010/PN.BJM and the Banjarmasin High Court decision Number 04/Pid.Sus/2011/PT.BJM. PT GJW was accused of committing several corruption-related acts, so that it was seen as a continuing act. PT Nusa Konstruksi Enjiniring (PT NKE) that previously known as PT Duta Graha Indonesia (PT DGI) is the first corporation that was convicted in a corruption case in 2019 after the Supreme Court Regulation Number 13 of 2016 concerning Procedures for Handling Criminal Cases Criminal by Corporations [6].

This condition is increasingly becoming interesting to analyze after the issuance of the Omnibus Law, namely Law Number 11 of 2020 concerning Job Creation. In Indonesia, the first Omnibus Law was promulgated on November 2, 2020, containing 15 Chapters, 186 Articles, and reaching 1,187 pages. As usual, the development of legal subjects in various laws outside the Criminal Code, the Job Creation Law also includes corporations as legal subjects. The fundamental problem is that the structure of the Job Creation Law is different from other ordinary laws, and each cluster mentions corporate criminal liability in a diverse and unsynchronized manner [7]. It encourages the importance of conducting an academic study through research entitled "Model for the Formulation of Corporate Criminal Liability System in Omnibus Law Number 11 of 2020 Concerning Job Creation". The issue that is the focus of discussion in this paper is how the formulation of corporate criminal liability in Law Number 11 of 2020 concerning Job Creation?, and what is the ideal corporate criminal responsibility formulation model in an Omnibus Law?

\section{Research Method}

This research uses a normative juridical research method, which aims to reveal the reality, to what extent certain legislations are vertically compatible, or have horizontal compatibility when it comes to equal legislation in the same field. This study uses secondary data, which among other things refers to primary legal materials in the form of Law Number 11 of 2020 
concerning Job Creation. The collected data were analyzed using normative qualitative data analysis methods.

\section{Results and Discussion}

\subsection{The Formulation of Corporate Criminal Liability in Law Number 11 of 2020 concerning Job Creation}

The determination of a corporation as a legal subject in criminal law deviates from the criminal law regulation, namely the Criminal Code. Normatively, this is not a problem, considering that in the Criminal Code, there is a provision on the Bridge Article (Article 103 KUHP) that allows the development of provisions outside the Criminal Code to deviate from the Criminal Code. However, the formulation of criminal liability against corporations that commit criminal acts always creates conflict in conceptual and pragmatic matters. At the conceptual level, there is a principle of error in criminal law which reads "nulla poena sine culpa" or "keine strafe ohne schuld" or "actus non facit reum nisi mens sit rea". Which means there is no crime without error. Of course, it will create difficulty in being responsible and punishing the corporation in connection with the absence of mental attitude or mens rea elements [8].

Apart from that, the difficulty is also determining which criminal sanctions to choose for corporations. The criminal sanctions in the primary criminal law in Indonesia, namely the Criminal Code, still design criminal sanctions that can be imposed on natural persons or humans. Whereas at the practical level, there is a skeptical view of the effectiveness of corporate criminal liability in relation to the issue of whether the corporation is an appropriate target for liability in criminal law and also whether corporate liability in criminal law diverts attention from criminal liability to criminal offenders [1][2]. To answer the debate related to these two matters, theories that examine the criminal responsibility of the criminal offender have emerged. Identification theory, Vicarious Liability theory, and Strict Liability theory are among them.

Identification Theory or Alter Ego Theory states that the will power of a corporation's managers represented the will power of corporations. The managers and directors represent the brain, intelligence, and will of the corporations. A sufficiently high-ranking corporate member acts not as an agent of the corporation but as the corporation itself and represents the nervous system that controls what the corporations do. It means that the corporation can only be held accountable for individual actions acting on behalf of the corporation, and that person has a high position or plays a crucial function in the corporate decision-making structure. Meanwhile, according to the theory of Vicarious Liability, a corporation can be held accountable if an employee commits a crime in carrying out their work within the scope of work on behalf of the corporation. In this case, it is not limited to the actions of managers and directors.

Meanwhile, according to the theory of Strict Liability (strict criminal responsibility), corporations can be held accountable based on law if the corporation violates or does not fulfill certain obligations/conditions/situations determined by law. For example, in the case of the law stipulating as an offense for Corporations that run their business without a permit, corporations holding a license that violates the conditions (situations) specified in the license, and Corporations operating uninsured vehicles on public roads.

Although theoretically there have been theories of corporate criminal responsibility, the main point is how it is regulated in law. The more complete the regulation of corporate criminal 
liability in law, the more potential it will be to minimize the potential for juridical problems in its enforcement.

It is also included in the Omnibus Law Number 11 of 2020 concerning Job Creation (starting now referred to as the Job Creation Law) which contains provisions on corporate criminal liability. The Job Creation Law comprises 186 articles, which are divided into 9 clusters, which include: Increasing the Investment Ecosystem and Business Activities Investment Requirements; Employment; Convenience, Protection, and Empowerment of MSMEs and Cooperatives; Ease of Doing Business; Research and Innovation Support; The land acquisition; Economic Zone; Central Government Investment and Ease of Government Projects; and, Implementation of Government Administration to Support Job Creation. Within these 9 clusters, there are regulations related to corporate criminal liability spread across several articles.

Chapter III Improvement of Investment Ecosystems and Business Activities Investment Requirements, Part Three: Simplification of Basic Requirements for Business Licensing, Land Acquisition, and Land Use.

Law Number 26 of 2007 concerning Spatial Planning

Article 74

(1) In the event that the criminal act as intended in Article 69, Article 70, or Article 71 is committed by a corporation, in addition to imprisonment and fines against its management, the punishment that can be imposed on the corporation is in the form of a penalty with a weight of $1 / 3$ of the criminal penalties as referred to in Article 69, Article 70, or Article 71.

(2) In addition to the fine as referred to in paragraph (1), the corporation may be subject to additional penalties in the form of:

a) Revocation of Undertaking Licensing; and/or

b) Revocation of legal entity status.

Part Four Simplification of Sector Business Licenses and Convenience: Law Number 31 of 2004 concerning Fisheries as lastly amended by Law Number 45 of 2009 regarding Amendments to Law Number 312004 concerning Fisheries

Article 101 stated that in the case of a criminal act as referred to in Article 84 paragraph (1), Article 85, Article 86, Article 87, Article 88, Article 90, Article 91, Article 93, or Article 94 is committed by the corporation, the charges and criminal sanctions shall be imposed on its management and against the corporation will be subject to a fine with an additional 1/3 of the penalty charged.

Law Number 18 of 2013 concerning Prevention and Eradication of Forest Destruction, Article 78 Paragraph (11) stated that the criminal offense as referred to in Article 50 paragraph (1) and paragraph (2) if it is committed by a corporation and/or on behalf of the corporation, the corporation and its management are subject to criminal fine with a weighting of $1 / 3$ of the main criminal fine.

Article 85 Paragraph (2) stated that corporations carrying heavy equipment and/or other tools commonly or reasonably suspected to be used to transport forest products in the forest area without a Business Permit as referred to in Article 12 letter g should be penalized for:

a. The imprisonment is imprisonment for a minimum of 5 years and a maximum of 15 years and a fine of at least IDR 5,000,000,000.00 and a maximum of IDR 15,000,000,000; and/or

b. Corporations are subject to a weighting of $1 / 3$ of the criminal fine imposed. 
Article 92 Paragraph (2)

Corporations that:

a. Carry out plantation activities without a Business License in the forest area as referred to in Article 17 paragraph (2) letter b; and/or

b. Carrying heavy equipment and/or other tools commonly or reasonably suspected to be used for carrying out plantation activities and/or transporting garden products in forest areas without Business Licensing as referred to in Article 17 paragraph (2) letter a;

Shall be sentenced to imprisonment for the management of a minimum of 8 years and a maximum of 20 years and a fine of at least IDR 20,000,000,000.00 and a maximum of IDR 50,000,000,000.00 and/or corporations are subject to a weighting of $1 / 3$ of the principal fine.

Article 93 Paragraph (3) stated that corporations that:

a. Transport and or receive custody of plantation products originating from plantation activities in the forest area without a Business Permit as referred to in Article 17 paragraph (2) letter c;

b. Sell, control, own, and/or store plantation products originating from plantation activities in forest areas without a Business License as referred to in Article 17 paragraph (2) letter d; and/or

c. Buying, marketing, and/or processing garden products from plantations originating from plantation activities in forest areas without a Business Permit as referred to in Article 17 paragraph (2) letter e,

Shall be sentenced to imprisonment for the management of a minimum of 5 years and a maximum of 15 years and/or a fine of at least IDR 5,000,000,000.00 and a maximum of IDR $15,000,000,000.00$ and/or corporations are subject to a weighting of $1 / 3$ of the criminal fine imposed.

Based on the formulation of these articles, it can be analyzed that the regulations regarding criminal liability for corporations in the Job Creation Law are regulated separately with no similarity in formulating methods. Some have formulated the types of main and additional crimes, and some have not. Likewise, who can be held accountable for corporate mistakes, those who say that the management can be accounted for, but there are also those who do not specifically call it.

\subsection{The Ideal Corporate Criminal Liability Formulation Model in an Omnibus Law}

The Omnibus Bill is a technique of forming laws to change and combine regulations regarding interrelated matters originating from several laws at once in one law [9][10]. In Indonesia, the Codification form has already been recognized, which is almost similar to the Omnibus, as a mechanism for preparing a specific legal material arranged systematically, completely, and thoroughly [1][2]. Systematic because the sub-systems or parts in the codification should not conflict. Meanwhile, complete and finished is to guarantee that there are no more provisions outside codification that become legal rules so that codification alone can be enforced as a source of law. The codification system prioritizes and idealizes the writing and drafting of laws in one integrated unit regarding the subject and object regulated in each statute text. 
Codification systems can be distinguished between legislative codification and executive codification. Legislative Codification, namely the drafting of laws by branches of legislative power or people's representative institutions intended as one unified text, such as the Law on Election Implementation, which comes from various statutory texts interrelated with regulating material on general elections. Meanwhile, the second, the Executive Codification, namely that the compilation of an integrated text which is in harmony with various other laws, is carried out by the Government with reference to all relevant laws and regulations to facilitate the regulated legal subjects and all the people to seek justice, and find legal truth [9][10].

Slightly different from Codification, the Omnibus Law system prioritizes and idealizes writing and compilation. In addition to being integrated, it is also harmonious with various statutory materials that regulate subjects and objects different from other laws in a single constitutional state-based system of law as the highest source of law [11]. The Omnibus Law system can be carried out with laws that are not too thick, sectoral, but can also be made thick, comprehensive, and integrated depending on the needs. With a short or thicker and integrated law, the Omnibus Law system can be combined with an executive codification system, in which laws as legislative acts can be formed in a more productive, more numerous, and qualified manner, but afterward are codified by the Government based on and with reference to the related laws that have been got the approval of the people's representative institutions.

So that to integrate the provisions between the various laws included in the Job Creation Law, of course, a general provision is needed which generally regulates all the provisions in the omnibus law. Including corporate criminal liability. Regulations regarding corporate criminal responsibility scattered in several articles in the Job Creation Law can cause juridical problems in its enforcement. And when viewed as a system as a whole, of course, this will seem unsystematic. The position of the Job Creation Law as a law outside the Criminal Code has a consequence that regulations regarding matters that deviate from the Criminal Code must be carried out very carefully, completely, and in detail so as not to cause juridical problems.

Concerning corporate criminal liability, there are several things that legislators must pay attention to in formulating this provision, namely as follows:

a. General criteria in terms of what the corporation can be held accountable for;

b. Who can be held accountable in the event of a mistake committed by the Corporation; and,

c. Types of punishment can be imposed, both the main and additional crimes.

\section{Conclusion}

The formulation of corporate criminal responsibility in Law Number 11 of 2020 concerning Job Creation is spread over several articles and is not formulated in the general provisions chapter. There is a lack of uniformity in the formulation of provisions between articles that accommodate them, such as those related to who can be accounted for and criminal sanctions that can be imposed.

The ideal formulation model for corporate criminal liability in an Omnibus Law is to accommodate it in the chapter on general provisions so that the regulation will be uniform and applicable to the entire content of the law. 


\section{References}

[1] N. S. P. Jaya and N. Serikat, Hukum pidana khusus. Semarang: Badan Penerbit Universitas Diponegoro, 2016.

[2] M. H. Pura and O. Senjaya, Hukum Tindak Pidana Khusus. Yogyakarta: Deepublish, 2020.

[3] S. H. Sudarto, Hukum Pidana I, 2nd Ed. Semarang: Fakultas Hukum Universitas Diponegoro, 1990.

[4] A. Hamzah, Hukum Pidana Indonesia. Jakarta: Sinar Grafika, 2017.

[5] A. Hamid, "Analysis of the Importance of Omnibus Law "Cipta Kerja" In Indonesia," Int. J. Sci. Res. Manag., vol. 8, pp. 236-250, 2020.

[6] CNN Indonesia, "Vonis Perdana Korporasi Korup, PT NKE Didenda Rp700 Juta," 2019. https://www.cnnindonesia.com/nasional/20190103193656-12-358318/vonis-perdanakorporasi-korup-pt-nke-didenda-rp700-juta.

[7] K. Tejomurti and S. Sukarmi, "The Critical Study of the Omnibus Law Bill on Job Creation Based on John Rawls View on Justice," Unnes Law J., vol. 6, no. 2, pp. 187-204, 2020.

[8] G. Panebianco, "The Nulla Poena Sine Culpa Principle in European Courts Case Law," in Human rights in European criminal law, Springer, 2015, pp. 47-78.

[9] J. Asshiddiqie, Omnibus Law dan Penerapannya di Indonesia. Jakarta: Konstitusi Press dan Jimly Law School of Law and Government, 2020.

[10] R. Christiawan, Omnibus Law: Teori dan Penerapannya. Jakarta: Bumi Aksara, 2021.

[11] A. H. Siagian, "Omnibus Law in the Perspective of Constitutionality and Legal Politics," Jambura Law Rev., vol. 3, no. 1, pp. 93-111, 2021. 